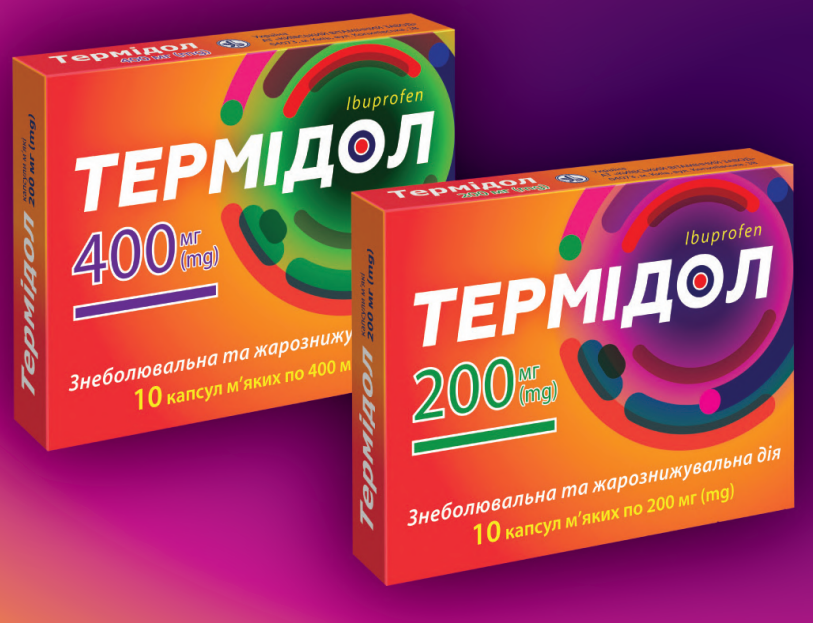

Терміоол (ібупрофен) застосовується для симптоматичного лікування легкого та помірного болю різного походження (головний, зубний біль, болісні менструачії), в тому числі прu засmydi ma гарячці.
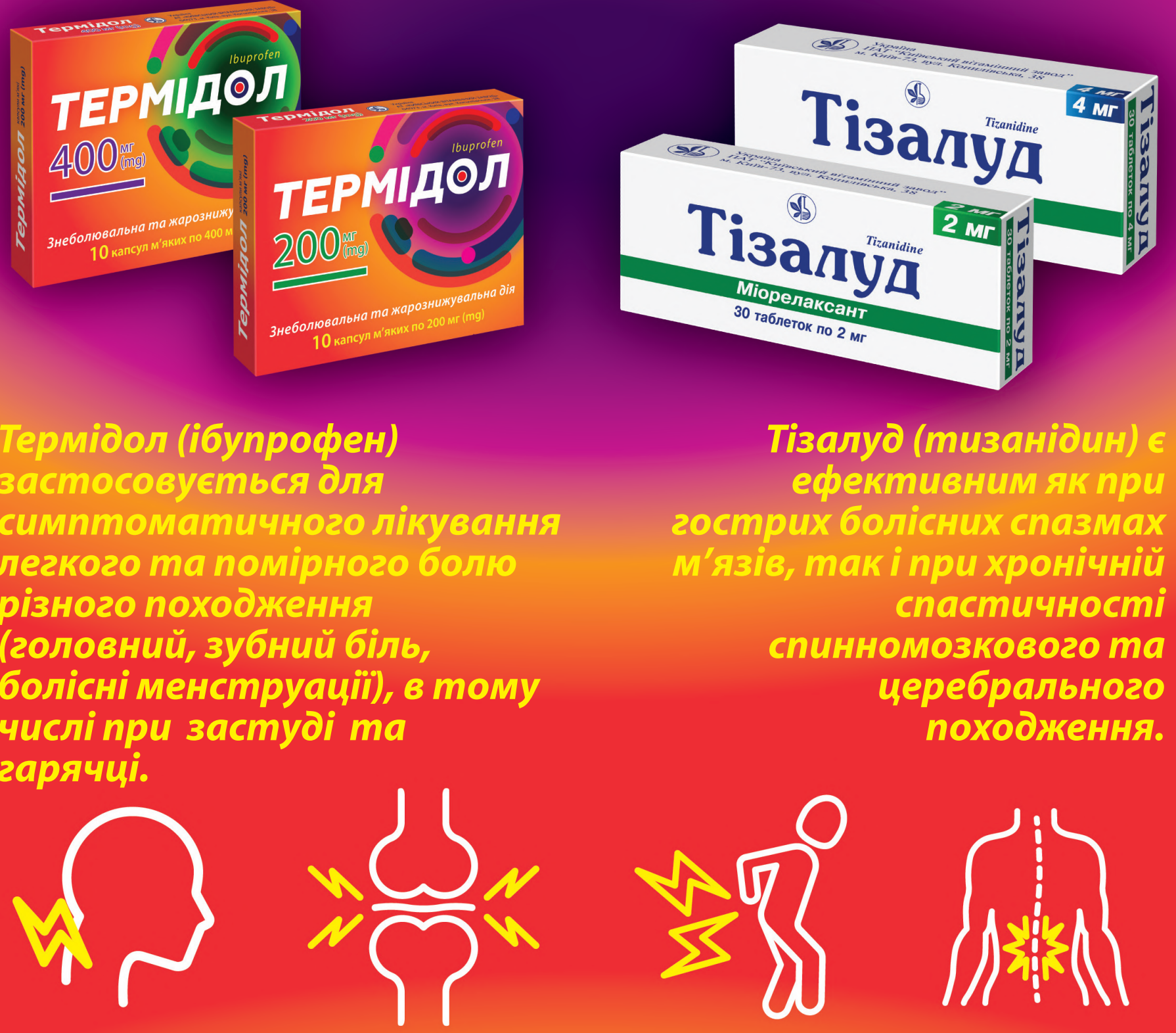

Тізалуд (тизаніоин) є ефективним як при zострих болісних спазмах м'язів, так і при хронічній cnacmuчносmi спинномозкового ma церебрального походження.

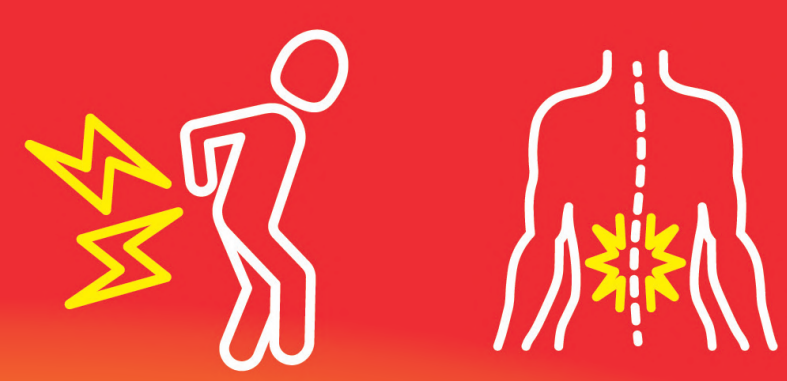

Частота розвитку шлунково-кишкових побічних реакцій (\%) при застосуванні плацебо/ібупрофену та ібупрофену з тизанідином у хворих з болем у спині за даними клінічного дослідження*

КИїВСьКИЙ ВТТАМНННИЙ ЗАВОД Gricuno deg ramupariciol?

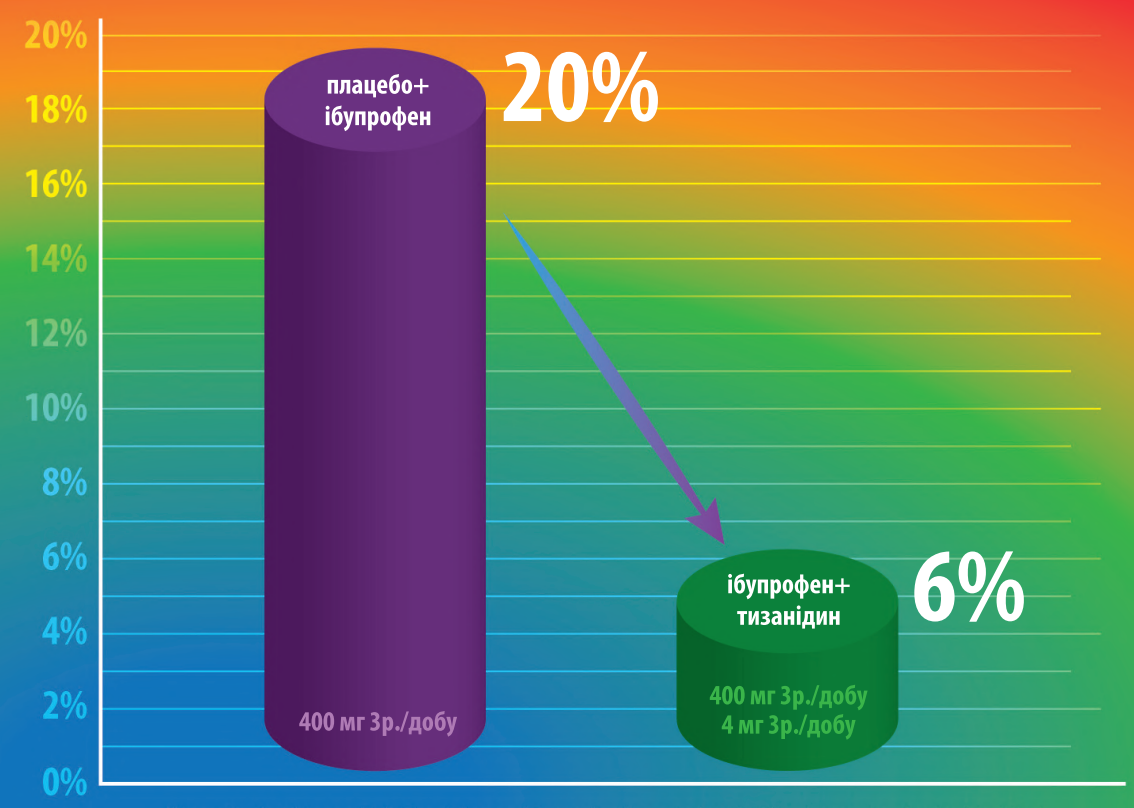

Інформація про лікарський засіб, призначена для розповсюпження серед медичнихі фармацевтичних працівників на спеціалізованих семінарах, конференціях, симпозіумах з медичної тематики. Реєстрацй̈не посвідчення М03 України: Термідол № UA/18326/01/01 та № UA/18326/01/02 від 17 вересня 2020 року; Тізалуд № UA/7594/01/01 та № UA/7594/01/02 325 жовтня 2017 року. 


\title{
Міорелаксанти центральної дії: роль і місце в лікуванні болю у спині
}

\author{
О.я. Міщенко, Н.В. Бездітко
}

Національний фармацевтичний університет, Харків, Україна

\begin{abstract}
Анотація. Біль у спині - стан, який займає 1-ше місце у структурі больових синдромів і залишається однією з найбільш актуальних проблем медицини. У клінічній практиці різні патофізіологічні варіанти больових синдромів часто поєднуються, що ускладнює вибір оптимального засобу лікування. Мета: актуалізувати інформацію щодо ефективності та безпеки застосування міорелаксантів центральної дії (МЦД) при лікуванні болю у спині, зокрема тизанідину. Об'єкт і методи дослідження: аналіз релевантних джерел інформації щодо ефективності та безпеки застосування МЦД, зокрема тизанідину, при лікуванні болю у спині. Результати. На сьогодні високий рівень доказовості при неспецифічному больовому синдромі в ділянці спини серед лікарських препаратів мають нестероїдні протизапальні препарати (НПЗП) і МЦД. Основні підходи до застосування МЦД при болю у спині, що визначені клінічними рекомендаціями: клінічні дані не підтверджують перевагу одного МЦД над іншим щодо опорно-рухового апарату; МЦД не вважаються терапією 1-ї лінії при захворюваннях опорно-рухового апарату; при гострому болю у спині в якості допоміжної терапії можуть застосовуватися МЦД; при гострому болю у спині слід застосовувати МЦД короткочасно (2 тиж). Висновки. Результати аналізу проведених клінічних досліджень у поєднанні з накопиченим досвідом клінічного застосування підтверджують ефективність МЦД для лікування больових спазмів, зокрема при болю у спині. Серед існуючих МЦД тизанідин $\epsilon$ ефективним препаратом з оптимальним профілем безпеки, можливістю поєднаного застосування з НПзП і здатністю знижувати їх гастротоксичність.
\end{abstract}

Ключові слова: біль у спині, центральні міорелаксанти, клінічна ефективність, безпека, тизанідин.

\section{Вступ}

Біль у спині - стан, який займає 1-ше місце у структурі больових синдромів і залишається однією з найбільш актуальних проблем медицини. У сучасному світі біль у спині турбує не тільки осіб старшого віку. Згідно з даними останніх досліджень він відмічається у $33,9 \%$ дорослих та у $46,6 \%$ підлітків [1-4]. За даними деяких авторів, протягом життя біль у спині відчувають 85,5\% людей [5]. Біль у спині - не тільки медична, але й соціально-економічна проблема. Він лідирує як причина звернення за лікарською допомогою, тимчасової непрацездатності, інвалідизації, а сукупні витрати, пов'язані з цією патологією, минулого року становили 365 млрд дол. США [3].

Залежно від провідного патофізіологічного механізму розрізняють ноцицептивний, нейропатичний і психогенний біль.

Ноцицептивний біль, як правило, має гострий характер, пов'язаний з активацією больових рецепторів (ноцицепторів) у результаті травми, запалення, ішемії суглобів хребта і навколишніх тканин. Ноцицептивний біль зазвичай характеризується чіткою локалізацією, посилюється при русі і слабшає у спокої.

Нейропатичний біль виникає в результаті патологічного збудження нейронів у периферичній або центральній нервовій системі (ЦНС), що відповідають за реакцію на фізичне пошкодження організму (звичайний біль). Найчастіше він пов'язаний з ураженням нервових корінців при грижах міжхребцевих дисків, ірадіює в кінцівку, супроводжується змінами поверхневої чутливості і сухожильних рефлексів, має хронічний характер.

У разі вираженого больового синдрому, який відзначається тривало, коли при ретельному обстеженні не вдається виявити адекватної фізичної причини або соматичного захворювання, можливо говорити про психогенний біль.

Залежно від причини виникнення виділяють вертеброгенний і невертеброгенний біль у спині. Перший може бути зумовлений змінами міжхребцевих дисків, тіл хребців, міжхребцевих суглобів і зв'язкового апарату хребта, в результаті чого виникає скутість нервових корінців або спинномозкових нервів. Невертеброгенний біль пов'язаний із соматичною патологією. Для полегшення встановлення діагнозу лікарем загальної практики в даний час також виділяють неспецифічний біль у спині, що пов'язаний зі скелетно-м'язовими розладами без ознак ураження нервових корінців і специфічних пошкоджень хребта [6].
Визначення причини і патофізіологічного механізму болю у конкретного хворого $\epsilon$ основою ефективної стратегії лікування. У клінічній практиці різні патофізіологічні варіанти больових синдромів часто поєднуються, що ускладнює вибір оптимального засобу лікування.

Мета роботи: актуалізувати інформацію щодо ефективності та безпеки застосування міорелаксантів центральної дії (МЦД) при лікуванні болю у спині, зокрема тизанідину.

\section{0б'єкт і методи дослідження}

Аналіз релевантних джерел інформації щодо ефективності та безпеки застосування МЦД при лікуванні болю у спині, зокрема тизанідину.

\section{Результати та їх обговорення}

Сучасні клінічні рекомендації передбачають комплексний підхід до вирішення проблеми болю в спині, поєднання медикаментозних і немедикаментозних методів, але зовсім уникнути застосування лікарських препаратів неможливо. Прогрес фармакології та фармації надає лікарям все більш досконалі ліки, розширює їх асортимент, проте універсального лікарського засобу, який міг би допомогти всім без винятку пацієнтам з болем у спині, поки не існує. У такого «ідеального препарату» повинні бути наступні властивості:

- сильний і стійкий знеболювальний ефект;

- позитивний вплив на якість життя хворих;

- сприятливий профіль безпеки;

- доведені в добре організованих рандомізованих контрольованих клінічних дослідженнях ефективність і безпека при застосуванні у широкого контингенту пацієнтів;

- невисока (прийнятна) вартість [6, 7].

На сьогодні високий рівень доказовості (A) при неспецифічному больовому синдромі в ділянці спини серед лікарських засобів мають нестероїдні протизапальні препарати (НПЗП) і міорелаксанти [6, 7]. Болісний м'язовий спазм $\epsilon$ важливою складовою складного причинно-наслідкового каскаду виникнення і розвитку болю в спині. На початку патологічного процесу спазм м'язової тканини виконує компенсаторнопристосувальну роль (рис. 1). 3 розвитком патології спазм стає додатковим джерелом больових імпульсів і зумовлює 
формування хибного кола «біль - м'язовий спазм - біль». 3 урахуванням цього факту застосування у складі фармакотерапії міорелаксантів $\epsilon$ патогенетично обґрунтованим [14-16]. Комбінування міорелаксантів з НПЗП та анальгетиками значно підвищує ефективність лікування і дозволяє знизити дози останніх [14].

Рисунок 1 Рефлекторне напруження м'язів - істотний фактор у посиленні хронічного больового синдрому

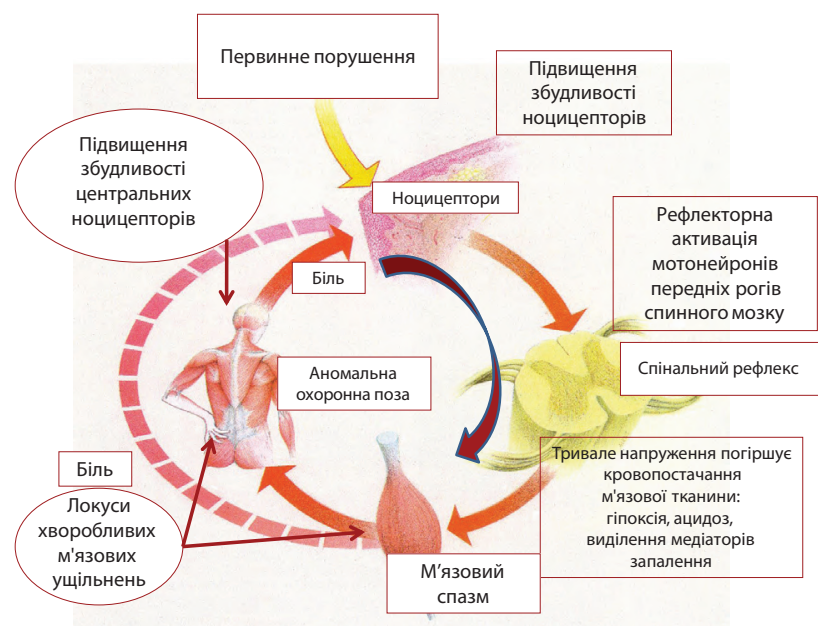

Міорелаксанти - клас лікарських препаратів, які мають здатність вибірково розслабляти скелетні м'язи. Існуючі в даний час міорелаксанти поділяють на препарати периферичної та центральної дії. Міорелаксанти периферичної дії блокують нервово-м'язову передачу в місці контакту нервового волокна і мембрани скелетного м'яза. Міорелаксанти центральної дії впливають на центральні механізми регуляції тонусу скелетних м'язів у головному і спинному мозку, усувають спастичність i пов'язаний зі спазмом біль. Вони застосовуються при різних станах, які супроводжуються спастичністю і болючими м'язовими спазмами (рис. 2). МЦД сприяють зменшенню вираженості болю, збільшенню обсягу рухів, запобіганню утворення контрактур і в цілому — поліпшенню функціональної здатності опорно-рухового апарату [8-12, 14, 15].

Рисунок 2 Класифікація МЦД

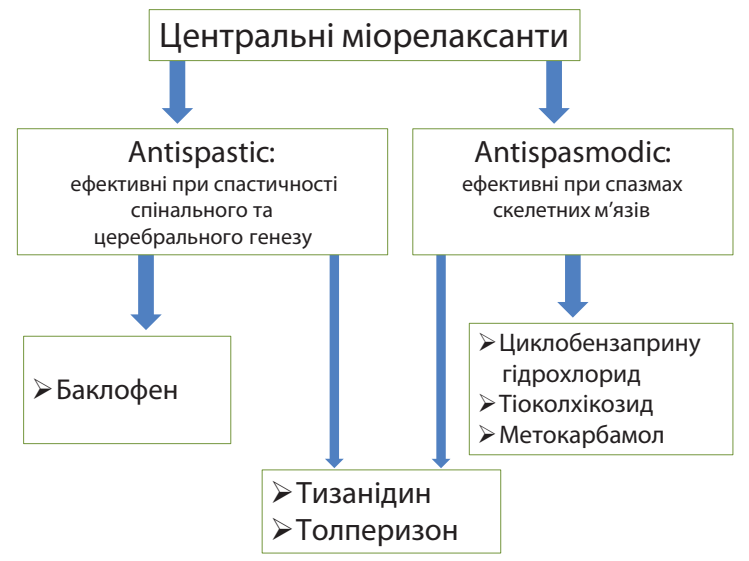

Систематичні огляди та метааналізи підтримують застосування МЦД для короткострокового полегшення гострого болю в спині, коли НПЗП та/або парацетамол неефективні або погано переносяться [11, 17-21].

Основні підходи до застосування МЦД при болю у спині визначені клінічними рекомендаціями:

- клінічні дані не підтверджують перевагу одного МцД над іншим щодо опорно-рухового апарату (рівень доказовості B);

- МЦД не вважаються терапією 1-ї лінії при захворюваннях опорно-рухового апарату (рівень доказовості С);
- при гострому болю у спині в якості допоміжної терапії можуть застосовуватися МЦД (рівень доказовості В);

- при гострому болю у спині слід застосовувати МЦД короткочасно (2 тиж) (рівень доказовості С) [15, 21].

Фармакологічна характеристика основних МЦД наведена у таблиці.

Усі зазначені МЦД дещо відрізняються за механізмом дії, всі вони знижують м'язовий тонус та виявляють знеболювальний ефект. На сьогодні клінічні дані не підтверджують перевагу одного МЦД над іншим у разі застосування при захворюваннях опорно-рухового апарату [13, 22]. Практично всі препарати виявляють седативний ефект, який у певних клінічних ситуаціях (наприклад при збудженні) $\epsilon$ корисним для пацієнта, але в інших ситуаціях розглядається як побічний ефект, оскільки протипоказаний пацієнтам, діяльність яких потребує швидкої реакції (водії та ін.). Побічними ефектами, які притаманні всім МЦД, $\epsilon$ здатність знижувати артеріальний тиск до розвитку ортостатичної гіпотензії, що може підвищувати ризик падіння пацієнтів [23]. Циклобензаприну гідрохлорид потенціює дію антидепресантів, тому його поєднане застосування з антидепресантами, такими як селективні інгібітори зворотного захоплення серотоніну, селективні інгібітори зворотного захоплення серотоніну та норадреналіну, трициклічні антидепресанти, інгібітори MAO, або протягом 14 днів після їх відміни, трамадолом, бупропіоном, меперидином, верапамілом може зумовлювати розвиток серотонінового синдрому, що характеризується тремором, галюцинаціями, ригідністю. Препарат протипоказаний під час фази відновлення після гострого інфаркту міокарда та за наявності порушень серцевого ритму та провідності, включаючи блокади, або застійної серцевої недостатності, а також при гіпертиреозі. Циклобензаприну гідрохлорид може посилювати дію алкоголю, барбітуратів та інших препаратів, що пригнічують ЦНС, може підвищувати ризик виникнення судомних нападів у пацієнтів, які застосовують трамадол, або може блокувати антигіпертензивну дію гуанетидину й аналогічних сполук [24].

Баклофен стимулює шлункову секрецію, викликає такі побічні реакції, як сонливість, запаморочення, порушення ходи, нудота, запор, діарея, артеріальна гіпотензія, загострення симптомів хвороби Паркінсона при поєднанні з леводопою. Важливо враховувати, що НПЗП ібупрофен уповільнює виведення баклофену, тому не можна поєднувати ці препарати, оскільки можливе передозування останнього [25].

Метокарбамол викликає сонливість або запаморочення, містить натрію гідросульфіт, який може спричинити реакції гіперчутливості та бронхоспазм; при внутрішньом'язовому та внутрішньовенному введенні можливий розвиток судинної екстравазації, тромбофлебіту [26].

Ймовірні побічні реакції тіоколхікозиду такі: сонливість, діарея, біль у шлунку, після внутрішньом'язової ін'єкції можливий розвиток вазовагальної непритомності, при одночасному застосуванні з НПЗП або парацетамолом - тяжкі випадки ураження печінки (фульмінантний гепатит). Препарат протипоказаний дітям віком $<16$ років [27].

Серед МЦД добре зарекомендував себе перевірений препарат для лікування болісного м'язового спазму тизанідин. Механізм його дії пов'язаний зі стимуляцією пресинаптичних $a_{2}$-рецепторів, що призводить до пригнічення вивільнення збуджуючих амінокислот (глутамінова кислота, аспарагінова кислота), які стимулюють рецептори до N-метил-D-аспартату. Внаслідок цього на рівні проміжних нейронів спинного мозку відбувається пригнічення синаптичної передачі збудження, що призводить до зниження збудливості a- i p-мотонейронів у спинному мозку і, як наслідок, зникнення м'язового спазму. Тизанідин виявляє помірний центральний анальгезивний ефект, зумовлений пригніченням функції вставних нейронів задніх рогів спинного мозку. Він не впливає на нервово-м'язову передачу, його міорелаксивний ефект не супроводжується зниженням м'язової сили. До важливих переваг цієї молекули слід віднести ії гастропротекторні властивості, зумовлені впливом на а му результаті призводить до зниження секреції хлороводневої кислоти у шлунку [28]. Це визначає безпеку застосування тизані- 
Таблиця Порівняльна фармакологічна характеристика МЦД

\begin{tabular}{|c|c|c|c|}
\hline Препарат & Механізм дії & Фармакологічні ефекти & Несприятливі побічні реакції \\
\hline Тизанідин & $\begin{array}{l}\text { Стимулює } a_{2} \text {-адренорецептори, що пригнічує } \\
\text { вивільнення збуджуючих нейромедіаторних } \\
\text { амінокислот (глутамату і аспартату) як у спинному, } \\
\text { так і в головному мозку }\end{array}$ & 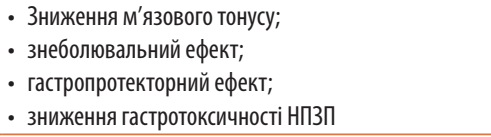 & Сонливість, ризик розвитку гіпотензії і брадикардії \\
\hline Толперизон & $\begin{array}{l}\text { Блокує a-канали інтернейронів, пригнічує } \\
\text { рефлекторну активність на спінальному рівні } \\
\text { в результаті гальмівного впливу ретикулярної формації }\end{array}$ & $\begin{array}{l}\text { - Зниження м'язового тонусу; } \\
\text { • знеболювальний ефект }\end{array}$ & $\begin{array}{l}\text { Головний біль, зниження артеріального тиску, } \\
\text { нудота, блювання, алергічні реакції }\end{array}$ \\
\hline $\begin{array}{l}\text { Циклобензаприну } \\
\text { гідрохлорид }\end{array}$ & $\begin{array}{l}\text { Вплив на ү-і а-мотонейрони і зниження рухової } \\
\text { активності }\end{array}$ & $\begin{array}{l}\text { - Зниження м'язового тонусу; } \\
\text { • значний седативний ефект; } \\
\text { • потенціювання ефекту антидепресантів }\end{array}$ & $\begin{array}{l}\text { Головний біль, зниження артеріального тиску, } \\
\text { нудота, блювання, запор; серотоніновий синдром } \\
\text { (галюцинації, тремор, ригідність) }\end{array}$ \\
\hline Баклофен & $\begin{array}{l}\text { Агоніст рецепторів ү-аміномасляної кислоти, пригнічує } \\
\text { моно- і полісинаптичні спінальні рефлекси }\end{array}$ & $\begin{array}{l}\text { • Зниження м'язового тонусу; } \\
\text { • помірний знеболювальний ефект; } \\
\text { • стимулювання шлункової секреції; } \\
\text { • потенціювання дії при поєднанні з трициклічними } \\
\text { антидепресантами }\end{array}$ & $\begin{array}{l}\text { Сонливість, запаморочення, порушення ходи, } \\
\text { нудота, запор, діарея, артеріальна гіпотонія, } \\
\text { загострення симптомів хвороби Паркінсона } \\
\text { при поєднанні з леводопою, НПЗП ібупрофен } \\
\text { уповільнює виведення препарату }\end{array}$ \\
\hline Тіоколхікозид & $\begin{array}{l}\text { Виявляє селективну афінність до ү-аміномасляної } \\
\text { кислоти і гліцинових рецепторів }\end{array}$ & $\begin{array}{l}\text { - Зниження м'язового тонусу; } \\
\text { • електроенцефалографічні дослідження показали, } \\
\text { що тіоколхікозид та його головний метаболіт } \\
\text { не спричиняють седативного ефекту }\end{array}$ & $\begin{array}{l}\text { Сонливість, діарея, біль у шлунку, після } \\
\text { внутрішньом'язової ін'єкції можливий розвиток } \\
\text { вазовагальної непритомності, при одночасному } \\
\text { застосуванні з НПЗП або парацетамолом — тяжкі } \\
\text { випадки ураження печінки (фульмінантний гепатит); } \\
\text { протипоказаний дітям віком <16 років }\end{array}$ \\
\hline Метокарбамол & Загальне пригнічення ЦНС & $\begin{array}{l}\text { - } 3 \text { ниження м'язового тонусу; } \\
\text { - знеболювальний ефект; } \\
\text { - } 3 \text { зачний седативний ефект; } \\
\text { - не впливає на нейронну провідність, нервово- } \\
\text { м'язову передачу та збудливість м'язів }\end{array}$ & $\begin{array}{l}\text { Сонливість або запаморочення; містить натрію } \\
\text { гідросульфіт, який може спричинити реакції } \\
\text { гіперчутливості та бронхоспазм; } \\
\text { при внутрішньом'язовому та внутрішньовенному } \\
\text { введенні можливий розвиток судинної екстраваза- } \\
\text { ції, тромбофлебіту }\end{array}$ \\
\hline
\end{tabular}

дину в поєднанні з НПзП, зокрема неселективними інгібіторами ЦОГ-2, що сприяє зниженню гастротоксичності НПЗП. Результати мультицентрового плацебо-контрольованого клінічного дослідження [29] свідчать, що при поєднанні тизанідину з диклофенаком частота кишково-шлункових побічних реакцій знижується практично втричі (з 36\% до 12\%) порівняно з такими при застосуванні монотерапії диклофенаком (рис. 3), а знеболювальний ефект зростає. У іншому дослідженні також показано, що комбінація ацеклофенак+тизанідин була більш ефективною, ніж окремо ацеклофенак, і мала сприятливий профіль безпеки при лікуванні гострого болю в спині [30]. Також відмічено, що інша комбінація - тизанідин+ібупрофен - була більш ефективною при лікуванні помірного або сильного гострого болю в спині, ніж плацебо та ібупрофен окремо. Про сонливість повідомили 20\% пацієнтів, які приймали тизанідин+ібупрофен. Усі, крім одного пацієнта, повідомили про цю подію після 1-го дня лікування без подальших подій під час лікування. Значно більше пацієнтів (20\%), які отримували лікування плацебо/ібупрофеном, мали побічні ефекти з боку шлунково-кишкового тракту, ніж ті, які отримували лікування тизанідином+ібупрофеном (6\%; p=0,002) [31] (рис. 4).

Рисунок 3 Частота розвитку шлунково-кишкових побічних реакцій при застосуванні диклофенаку та диклофенаку з тизанідином у хворих з болем у спині, за даними мультицентрового плацебо-контрольованого клінічного дослідження [29]

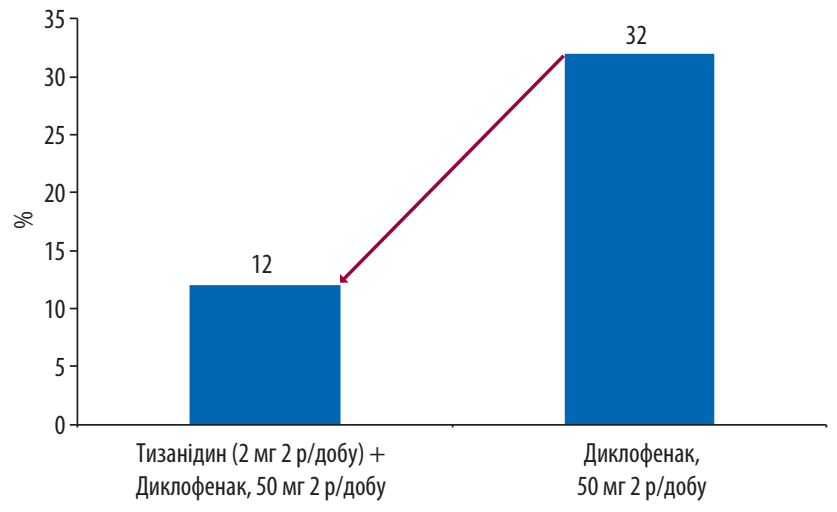

Рисунок 4 Частота розвитку шлунково-кишкових побічних реакцій при застосуванні плацебо/ібупрофену та ібупрофену з тизанідином у хворих з болем у спині, за даними клінічного дослідження [31]

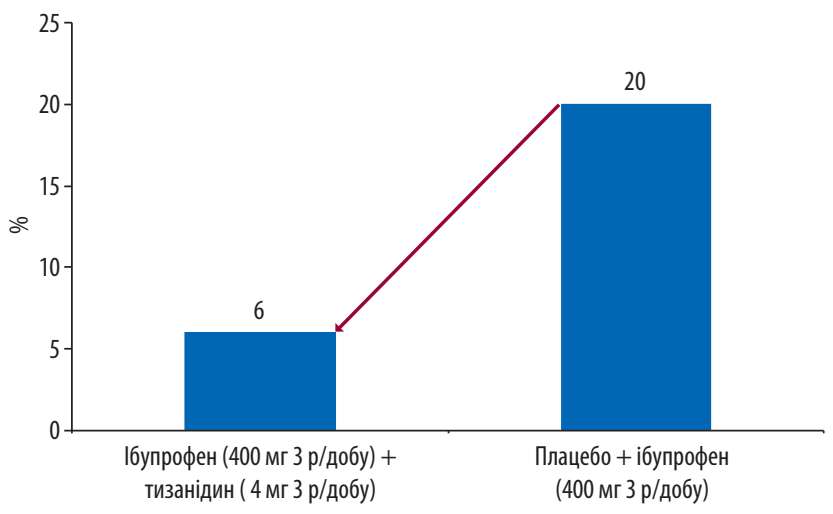

Усі вищезазначені унікальні властивості тизанідину дають можливість в одній лікарській формі отримати потужний засіб впливу на численні ланки складного патологічного процесу, яким $\in$ хворобливий м'язовий спазм. Численні дослідження довели ефективність і безпеку тизанідину при лікуванні не тільки вертеброгенної патології, а й інших захворювань, що супроводжуються болючим м'язовим спазмом, таких як розсіяний склероз, інсульт, різні травми, головний біль та ін. $[12,13]$.

На українському фармацевтичному ринку представлений тизанідин вітчизняного виробництва - препарат Тізалуд виробництва Київського вітамінного заводу. Тізалуд має більше ніж 10-річний досвід клінічного застосування, і за цей час зарекомендував себе як ефективний і безпечний препарат при лікуванні спастичних станів та м'язових спазмів. Так, у дослідженні професора Л.А. Дзяк та співавторів [32] Тізалуд (таблетки в дозі 2 і 4 мг, по 1 таблетці 3 рази на добу протягом 10 днів) призначали пацієнтам віком 18-65 років з вертеброгенною поперековою патологією (люмбалгії, люмбоішіалгія, радикулопатії) з помірним і вираженим больовим м'язово-тонічним синдромом. Усі паці$\epsilon$ нти отримували стандартну комбіновану терапію відповідно до існуючих протоколів лікування із застосуванням анальгети- 
ків, НПЗП, фізіотерапевтичного лікування, прийомів мануальної терапії. Оцінку ефективності проведеної терапії проводили з використанням опитувальника болю Макгілла (McGill Pain Questionaire, 1987), що дозволило оцінити динаміку суб'єктивного сприйняття больового синдрому пацієнтом, сенсорний та афективний компоненти болю. Для об'єктивізації клінічної динаміки використовували також шкалу «П'ятибальна оцінка вертеброневрологічної симптоматики». Отримані в дослідженні результати продемонстрували виражений позитивний вплив препарату Тізалуд (тизанідин) на зменшення вираженості болю і патологічного м'язового спазму, що полягало у збільшенні рухливості в ураженому відділі хребта, зниженні ступеня порушення постави. Ефект препарату був дозозалежним. Важливим моментом була швидкість настання міорелаксивного ефекту препарату у 65-70\% осіб у перші 5 днів терапії. У процесі лікування не відзначено побічних реакцій, пов'язаних з прийомом препарату Тізалуд (тизанідин).

Л.Ф. Климович та співавтори (2009) вивчали терапевтичні можливості препарату Тізалуд у пацієнтів із розсіяним склерозом. Дослідження показало, що Тізалуд чинить позитивний вплив на показники рухової активності хворих на розсіяний склероз та їх адаптацію при оцінці за стандартними міжнародними шкалами FS, EDSS, SCRIPPS. Авторами також відзначені фармакоекономічні переваги застосування Тізалуда у цієї категорії пацієнтів [33].

Н.Л. Боженко (2012) проведено вивчення впливу та безпеки застосування препарату Тізалуд у комплексі лікування міофасціальної больової дисфункції у пацієнтів із вертеброгенною патологією [34]. Результати дослідження дозволили встановити, що Тізалуд - ефективний препарат у комплексній терапії вертеброгенного міофасціального синдрому, який підвищує терапевтичну ефективність схем лікування дорсалгій. Застосування Тізалуду дозволяє скоротити відновний період та запобігти розвитку небажаних побічних явищ внаслідок впливу НПЗП завдяки його гастропротекторному ефекту.

Ефективність Тізалуду пролонгується та стабілізується при застосуванні засобів протизапальної, протинабрякової, судинної терапії та вітамінів. Загалом визначені тенденції в клінічній ефективності Тізалуду дозволяють рекомендувати цей препарат у складі комплексної терапії вертеброгенного міофасціального синдрому.

\section{Висновок}

Результати проведених клінічних досліджень у поєднанні 3 накопиченим досвідом клінічного застосування підтверджують ефективність МЦД у лікуванні при больових спазмах. Серед існуючих міорелаксантів тизанідин $\epsilon$ препаратом 3 оптимальним профілем безпеки і можливістю поєднаного застосування з НПЗП і здатністю знижувати їх гастротоксичність. Наявність на фармацевтичному ринку України вітчизняного препарату тизанідину (Тізалуд) розширює можливості боротьби з болем і спастичними синдромами у широкого контингенту пацієнтів.

\section{Список використаної літератури}

1. Bento T.P.F., Cornelio G.P., Perrucini P.O. et al. (2020) Low back pain in adolescents and association with sociodemographic factors, electronic devices, physical activity and mental health. J. Pediatr. (Rio J), 96(6): 717-724. D01: 10.1016/j.jped.2019.07.008.

2. Casiano V.E., Dydyk A.M., Varacallo M. (2021) Back Pain. In: StatPearls. Treasure Island (FL): StatPearls Publishing, PMID: 30844200.

3. Lo J., Chan L., Flynn S.A. (2021) Systematic Review of the Incidence, Prevalence, Costs, and Activity and Work Limitations of Amputation, Osteoarthritis, Rheumatoid Arthritis, Back Pain, Multiple Sclerosis, Spinal Cord Injury, Stroke, and Traumatic Brain Injury in the United States: A 2019 Update. Arch. Phys. Med. Rehabil., 102(1):115-131. D0l: 10.1016/j. apmr.2020.04.001.

4. Institute of Medicine (US) Committee on Advancing Pain Research, Care, and Education. Relieving Pain in America: A Blueprint for Transforming Prevention, Care, Education, and Research (2011) Washington (DC): National Academies Press.

5. Schmidt C., Raspe H., Pfingsten M. et al. (2007) Back pain in the German adult population. Spine, 37(18): 2005-2011.
6. Подчуфарова Е.В. (2012) Боль в спине: механизмы развития и лечение. Современная терапия в психиатрии и неврологии, 3: 47-54.

7. Practice guidelines for chronic pain management: an updated report by the American Society of Anesthesiologists Task Force on Chronic Pain Management and the American Society of Regional Anesthesia and Pain Medicine (2010) Anesthesiology, 112(4): 810-833.

8. Chou R., Deyo R., Friedly J. et al. (2017) Systemic Pharmacologic Therapies for Low Back Pain: A Systematic Review for an American College of Physicians Clinical Practice Guideline. Ann. Intern. Med., 166(7): 480-492. D01: 10.7326/M16-2458.

9. Abdel Shaheed C., Maher C.G., Williams K.A. et al. (2016) Efficacy and tolerability of muscle relaxants for low back pain: Systematic review and meta-analysis. Eur.J. Pain, 21(2):228-237. DOl: 10.1002/ejp.907.

10. Cashin A.G., Folly T., Bagg M. K. et al. (2021) Efficacy, acceptability, and safety of muscle relaxants for adults with non-specific low back pain: systematic review and meta-analysis. BMJ, 374: n1446. D0l: 10.1136/bmj.n1446.

11. Amaechi 0., Huffman M..M., Featherstone K. (2021) Pharmacologic Therapy for Acute Pain. Am Fam Physician. 2021 Jul 1; 104(1): 63-72. PMID: 34264611.

12. See S., Ginzburg R. (2008) Choosing a skeletal muscle relaxant. Am. Fam. Physician, 78(3): 365-370. PMID: 18711953.

13. Chou R., Peterson K., Helfand M. (2004) Comparative efficacy and safety of skeletal muscle relaxants for spasticity and musculoskeletal conditions: a systematic review. J. Pain Symptom. Manage, 28(2): 140-175. D0I: 10.1016/j.jpainsymman.2004.05.002. PMID: 15276195.

14. Zygmunt M., Sapa J. (2015) Muscle relaxants — the current position in the treatment of spasticity in orthopedics. Ortop. Traumatol. Rehabil., 17(4): 423-430. D01: 10.5604/15093492.1173500. PMID: 26468180.

15. Schreijenberg M., Koes B.W., Lin C.C. (2019) Guideline recommendations on the pharmacological management of non-specific low back pain in primary care - is there a need to change? ExpertRev. Clin. Pharmacol., 12(2): 145-157. D01: 10.1080/17512433.2019.1565992. Epub 2019 Jan 16. PMID: 30618319.

16. Подчуфарова Е.В., Яхно Н.Н. (2010) Боль в спине. ГОЭТАР-Медиа, Москва, 368 с.

17. Heinzlef 0.,Monteil-Roch I. (2012) Traitement médicamenteux de la spasticité dans la sclérose en plaques [Pharmacological treatment of spasticity in multiple sclerosis]. Rev. Neurol. (Paris), 168 Suppl. 3: S62-S68. doi: 10.1016/50035-3787(12)70049-8. PMID: 22721367.

18. Peck J., Urits I., Crane J. et al. (2020) Oral Muscle Relaxants for the Treatment of Chronic Pain Associated with Cerebral Palsy. Psychopharmacol. Bull., 50(4 Suppl. 1): 142-162. PMID: 33633423; PMCID: PMC7901132.

19. Abdel Shaheed C., Maher C.G., Williams K.A. et al. (2017) Efficacy and tolerability of muscle relaxants for low back pain: Systematic review and meta-analysis. Eur.J. Pain, 21(2):228-237.

20. Cashin A.G., Folly T., Bagg M.K. et al. (2021) Efficacy, acceptability, and safety of muscle relaxants for adults with non-specific low back pain: systematic review and meta-analysis. BMJ. 2021 Jul 7; 374: n1446.

21. Chou R, Oaseem A., Snow V. et al. (2008) Diagnosis and treatment of low back pain: a joint clinical practice guideline from the American College of Physicians and the American Pain Society. Ann. Intern. Med., 148(3): 247-248.

22. Chou R., Kim P. (2005) Drug Class Review on Skeletal Muscle Relaxants. http://www.ohsu. edu/ohsuedu/research/policycenter/DERP/about/methods.cfm

23. compendium.com.ua/dec/272742/

24. compendium.com.ua/dec/265520/

25. compendium.com.ua/dec/260727/

26. compendium.com.ua/dec/351869/

27. compendium.com.ua/dec/265593/

28. compendium.com.ua/dec/272742/

29. Efficacy and gastroprotective effects of tizanidine plus diclofenac versus placebo plus diclofenac in patients with painful muscle spasms (1998) Current Therapeutic Research, 59(1): 13-22.

30. PareekA.,Chandurkar N.,Chandanwale A.S. et al. (2009) Aceclofenac-tizanidine in the treatment of acute low back pain: a double-blind, double-dummy, randomized, multicentric, comparative study against aceclofenac alone. Eur. Spine J., 18(12): 1836-1842.

31. Berry H., Hutchinson D.R. (1988) Tizanidine and ibuprofen in acute low-back pain: results of a double-blind multicentre study in general practice. J. Int. Med. Res., 16(2): 83-91. D0I: 10.1177/030006058801600202.

32. ДзякЛ.А., СукВ.М., Цуркаленко А.С. (2009) Лечение мышечного спазма сиспользованием препарата Тизалуд. Здоров'я України, 62-63.

33. Климович Л.Ф., Федотова І.Ф. (2009) Тізалуд в комплексному лікуванні хворих на розсіяний склероз. Укр. вісн. психоневрол., 17(59): 84-87.

34. Боженко Н.Л. (2012) Тізалуд в лікуванні міофасціальної больової дисфункції. Острые и неотложные состояния в практике врача, 1: 21-24. 


\section{Central muscle relaxants: role and place in the treatment of back pain}

\section{O.Ya. Mishchenko, N.V. Bezditko}

National University of Pharmacy, Kharkiv, Ukraine

Abstract. Back pain is a condition that ranks first in the structure of pain syndromes and remains one of the most actual problems in medicine. In clinical practice, different pathophysiological variants of pain syndromes are often combined, which complicates the choice of optimal treatment. Objective: to update information on the effectiveness and safety of central muscle relaxants (CMR) in the treatment of back pain, including tizanidine. Object and methods of research: analysis of relevant sources of information on the effectiveness and safety of CMR, including tizanidine, in the treatment of back pain. Results. To date, non-steroidal anti-inflammatory drugs (NSAIDs) and

\section{Відомості про авторів:}

Міщенко Оксана Яківна - доктор фармацевтичних наук, професор, завідувач кафедри клінічної фармакології Інституту підвищення кваліфікації спеціалістів фармації Національного фармацевтичного університету, Харків, Україна. www.scopus.com/authid/detail. uri?authorld=57204440606.

Бездітко Наталія Володимирівна - доктор медичних наук, професор кафедри клінічної фармакології Інституту підвищення кваліфікації спеціалістів фармації Національного фармацевтичного університету, Харків, Україна. www.scopus.com/authid/detail. uri?authorld=6508203092.

\section{Адреса для кореспонденції:}

Міщенко Оксана Яківна

61001, Харків, пл. Захисників України, 17

E-mail: mishchoksana@gmail.com
CMR have a high level of evidence for non-specific back pain among drugs. The main approaches to the use of CMR for back pain, as determined by clinical guidelines: clinical data do not confirm the superiority of one CMR over another in musculoskeletal system diseases; CMR are not considered first-line therapy in musculoskeletal diseases; in acute back pain as an adjunct therapy can be used CMR; in acute back pain, CMR should be used for a short time (2 weeks). Conclusions. The results of the analysis of clinical trials in combination with the accumulated experience of clinical use confirm the effectiveness of CMR for the treatment of painful spasms, in particular for back pain. Among the existing CMR, tizanidine is an effective drug with an optimal safety profile, with the possibility of combined use with NSAIDs and the ability to reduce their gastrotoxicity.

Key words: back pain, central muscle relaxants, clinical efficacy, safety, tizanidine.

\section{Information about the authors:}

Mishchenko Oksana Ya. - Doctor of Pharmaceutical Sciences, Professor, head of the Department of Clinical Pharmacology, Institute for Advanced Training of Pharmacy Specialists of the National University of Pharmacy, Kharkiv, Ukraine. https://www.scopus.com/authid/detail. uri?authorld=6508203092.

Bezditko Natalia V. - Doctor of Medical Sciences, Professor of the Department of Clinical Pharmacology, Institute for Advanced Training of Pharmacy Specialists of the National University of Pharmacy, Kharkiv, Ukraine. https://www.scopus.com/authid/detail. uri?authorld $=6508203092$.

\section{Address for correspondence:}

Oksana Mishchenko

61001, Kharkiv, Zakhysnykiv Ukrainy sq., 17

E-mail:mishchoksana@gmail.com 